\title{
Phytochemical Analysis and Antimicrobial Studies of Lantana camara L.
}

\author{
Naveen Kumar Kudure Jayanna, ${ }^{1, *}$, Venkatesh ${ }^{2}$, Pradeepa Krishnappa ${ }^{3}$, \\ Santosh Kumar Shimoga Rajanna ${ }^{2}$ \\ ${ }^{1}$ Department of Studies in Microbiology, Davangere University, Davangere 577007, Karnataka, India \\ ${ }^{2}$ Department of Studies in Food Technology, Davangere University, Davangere 577007, Karnataka, India \\ ${ }^{3}$ Department of P.G. Studies and Research in Biotechnology, Sahyadri Science College, Shivamogga District, Karnataka, India
}

Received June 30, 2021; Revised August 13, 2021; Accepted November 21, 2021

\section{Cite This Paper in the following Citation Styles}

(a): [1] Naveen Kumar Kudure Jayanna, Venkatesh, Pradeepa Krishnappa, Santosh Kumar Shimoga Rajanna, "Phytochemical Analysis and Antimicrobial Studies of Lantana camara L.," Advances in Pharmacology and Pharmacy, Vol. 10, No. 1, pp. 54 - 68, 2022. DOI: 10.13189/app.2022.100105.

(b): Naveen Kumar Kudure Jayanna, Venkatesh, Pradeepa Krishnappa, Santosh Kumar Shimoga Rajanna (2022). Phytochemical Analysis and Antimicrobial Studies of Lantana camara L.. Advances in Pharmacology and Pharmacy, 10(1), 54 - 68. DOI: 10.13189/app.2022.100105.

Copyright $\bigcirc 2022$ by authors, all rights reserved. Authors agree that this article remains permanently open access under the terms of the Creative Commons Attribution License 4.0 International License

\begin{abstract}
Lantana camara is considered as a notorious weed and a popular ornamental plant. It has been observed since ancient times because the plants are an excellent source of medicine. Lantana camara has long been considered one of the most important medicinal plants in the world. Lantana camara is used in traditional medicine to treat cuts, swelling, ulcers, cataracts, biliary fever, itching, eczema and rheumatism. Different parts of the Lantana camara plant are used to treat colds, headaches, whooping cough, asthma, chicken pox, bronchitis, eye lesions, and high blood pressure. Lantana camara has been scientifically studied for various therapeutic activities like antibacterial, antioxidant, antipyretic, insecticidal, antimicrobial, wound healing etc. Various literatures have reported the phytoconstituents present in all parts of Lantana camara. In the current study, phytochemical analysis and antimicrobial activity of leaves and stem of Lantana camara were studied. The phytochemical analysis using chloroform and ethanol extracts for phenolic acids (Gallic acid) and flavonoids (Quercetin, Myricetin) by HPLC method in stem and leaves of Lantana camara. The present study evaluated the antimicrobial activity of ethanol and chloroform leaves extract against some pathogenic bacteria and fungi by using agar well diffusion method. This study can be concluded that Lantana camara of steam and leaves are comprised of bioactive compounds which possess antimicrobial activity against pathogenic bacteria and fungi.
\end{abstract}

Keywords Lantana camara, Crude Extract, Phytochemical Analysis, HPLC Analysis, Antimicrobial Activity

\section{Introduction}

Lantana camara, a noxious weed, has been increasing and is now mounted in lots of areas of the world, such as India. As it poses foremost threats to the ecosystem, it's been within side the cognizance of manage attempts. For the reason of these studies, diverse traits of Lantana camara are mentioned and strategies to fight its invasion in India had been studied. Results display that species have turn out to be threat and increasing its range. Present studies additionally indicate that extra than $80 \%$ of research cognizance on its effect use, toxicity and its healing makes use of only.

The phrase Lantana camara derives from Latin 'lento', this means that to bend $[1,2]$. The species became first defined and given its binomial call through Linnaeus in $1753[3,4]$. It is the genus of verbenaceae own circle of relatives with six hundred sorts present worldwide. Lantana camara, a local species of South, Central America and the Caribbean islands [5], has its presence recorded even in Brazil, Florida, Jamaica, Mexico, and Trinidad. The species is unfolded over huge geographical variety in 
neotropics, however none is pronounced from Old World $[6,7]$. Some species of Lantana camara also are believed to originate from Africa and one from India [8-10].

Lantana camara, additionally called wild sage, is a thorny multi-stemmed, deciduous shrub with a mean top of $2 \mathrm{~m}(6 \mathrm{ft})$. The shrub's ta xonomic function is described as belonging to the elegance of Magnoliopsida, order Lamiales, own circle of relatives Verbenaceae and genus Lantana. Stems are rectangular in outline, blanketed with bristly hairs whilst green, frequently armed or with scattered small prickles [11].

Berries of Lantana camara are round, fleshy, two-seeded drupe with to begin with inexperienced in shadeation and turning red and ultimately to blue-black shadeation. However, the berries are very toxic in nature aleven though those are appealing to bugs and birds. Seeds germination is simple and quicker in Lantana camara [12].

Although Lantana Camara is a noxious weed, it has several minor uses, mostly in herbal medicine. There are a number of research studies on the use of chemical components found in different parts of plant species. Studies show that extracts from the leaves can be used to combat antimicrobial, fungicidal, insecticidal and nematicidal problems. Its potential as a biocide has also been shown in various studies $[13,14]$.

Ethanolic extracts of Lantana Camara leaves and roots have been suggested for antibacterial interest. The in vitro antibacterial interest turned into accomplished via way of means of microdilution method. The extracts exhibited antimicrobial interest in opposition to Staphylococcus aureus, Proteus vulgaris, Pseudomonas aeruginosa, Víbriocholareae, Escherichia coli and multiresistant traces E. coli and S. aureus [6]. Three unique solvent extract of leaves and plants of 4 unique varities of Lantana Camara exhibited huge antibacterial interest E. coli, Bacillus subtilis and $P$. aeruginosa, while negative antibacterial interest in opposition to Staphylococcus aureus [3, 4, 13].

The antifungal activity of ethanol and hot water extract from Lantana camara was investigated against wood-destroying white and brown rot fungi. Both extracts exhibited efficient antifungal activity against white and brown rot fungi, however ethanol extract was highly potential at very low concentration $(0.01 \%)$ and also $\mathrm{L}$. camara was screened against Alternaria sp. which causes different plant diseases especially in vegetable plants $[5,8$, $10,11]$.

In the present work, the following objectives are to extraction of various phytoconstituents from Lantana camara using ethanol and chloroform solvents. Quantitative and qualitative analysis of crude extract by High performance liquid chromatography. To determine the Minimal Inhibitory Concentration in crude extract on bacterial and fungal strains. To evaluate the antibacterial and antifungal activity of crude extract.

\section{Materials and Methods}

\section{Collection and Identification of Plant Material}

Fresh leaves of Lantana camara, (Figure 1), which are free from disease and they were collected from outskirts of Kuvempu University at Shankaraghatta in Shimoga District, Karnataka, India. The taxonomic identification was confirmed by comparing with the authenticated specimen deposited at the Department of Botany, Kuvempu University. On that basis, we are identified the Lantana camara plant for used the phytochemical analysis and antimicrobial studies.

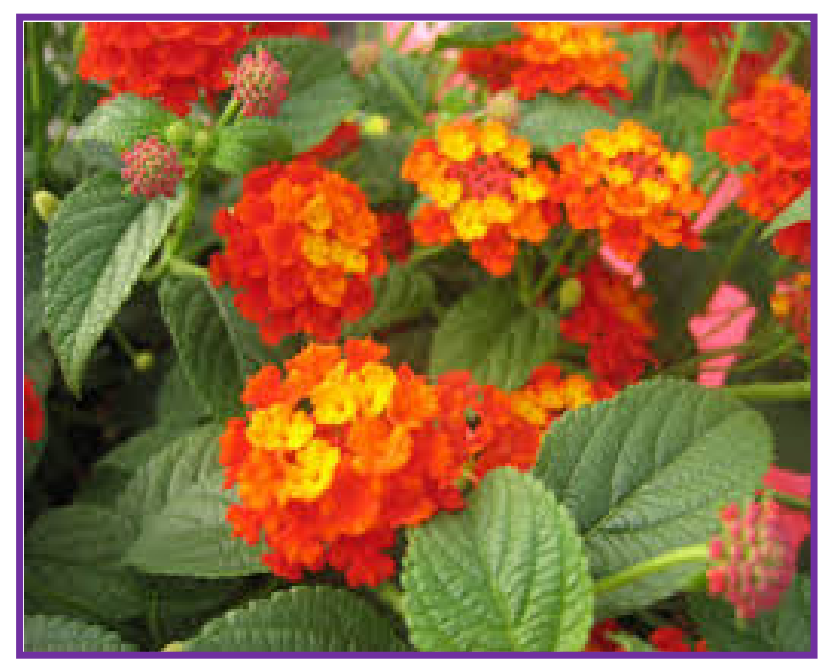

Figure 1. Flower of Lantana camara L. lantana

\section{Preparation of Plant Extracts}

The gathered plant leaves were brought to the research center. They were washed thoroughly with running water and again with sterile distilled water. The leaves were air dried on sterile blotter under shade. Thoroughly washed, dried leaves of Lantana camara were then powdered with the help of mechanical grinder. About 200g of shade-dried powder was filled in the thimble and extracted successively with chloroform and ethanol solvents in Soxhlet extractor for $24 \mathrm{~h}$. The solvent extracts were concentrated under reduced and preserved in airtight bottle until further use [15, $16]$.

\section{Development and Maintenance of Test Microorganism for Antimicrobial Studies}

Bacterial cultures such as Escherichia coli, Bacillus subtilis, Xanthomonas sp., Pseudomonas aeruginosa, Bacillus sp., Pseudomonas flurorescens and fungal cultures was followed by Aspergillus fumigatus, Aspergillus niger, Aspergillus terreus, Aspergillus flavus, Aspergillus sp., Fusarium oxysporum were obtained from the Department of Microbiology, Kuvempu University, Shivamogga, Karnataka, India. These strains were used as antimicrobial test organisms. The bacteria were maintained on Nutrient 
Broth (NB) at $37^{\circ} \mathrm{C}$ and fungi were maintained on Potato Dextrose Agar (PDA) media at $28^{\circ} \mathrm{C}$ in room temperature.

\section{Antibacterial Activity Crude Extract by Agar Well Diffusion Method}

Nutrient agar media was prepared, sterilized in autoclave at $121^{\circ} \mathrm{C}$ for 20 minutes. Then prepared media was poured into Petri plate and allowed for solidification. One day old test bacterial culture were uniformly swabbed on NA media by using sterile swabs and allowed to stand for 30 minutes. Wells were made on pre inoculated agar plates using sterile cork borer. In each plate 4 wells were made. Each extracts were prepared into different dilutions and added into wells using micropipettes. Then the plates were kept for incubation for $24 \mathrm{~h}$ at $37^{\circ} \mathrm{C}$. After incubation the zone of inhibition were observed and measured [17, $18]$.

\section{Antifungal Activity Crude Extract by Agar Well Diffusion Method}

Potato dextrose agar media was prepared and sterilized and poured into sterile Petri plates and allowed for solidification. Spore suspensions of fungal culture were prepared and inoculated on agar plates and spreader by using L-shaped glass rod and allowed for 30 minutes. Wells were made on pre inoculated agar plates using sterile cork borer. In each plate 4 wells were made. Each extracts were prepared into different dilutions and added into wells using micropipettes. Then the plates were kept for incubation for $48-72 \mathrm{~h}$ at room temperature. After incubation the zones of inhibition were observed and measured $[19,20]$.

\section{Determination of Minimal Inhibitory Concentration}

Minimal Inhibitory Concentration (MIC) values have been decided via way of means of Broth Dilution Method. Serial dilutions (final volume of $1 \mathrm{ml}$ ) of leaf extract of Lantana camara (2 to $0.25 \mathrm{mg} / \mathrm{ml}$ ) were performed with $0.9 \%$ saline. Following this, nine $\mathrm{ml}$ of nutrient broth become added. Broths were inoculated with $100 \mu \mathrm{l}$ of each bacterial suspension (5X104CFU) and incubated for $24 \mathrm{~h}$ at $37^{\circ} \mathrm{C}$. Ciprofloxacin was used as a positive control and $0.9 \%$ saline as negative control. After $24 \mathrm{~h}$, bacterial growth was assayed by measuring absorbance at $625 \mathrm{~nm}$ [21].

\section{High Performance Liquid Chromatography (HPLC) - UV Analysis}

Phenolic acids and flavonoids from chloroform and ethanol extracts of Lantana camara were analyzed by HPLC (Model LC-10ATVP. Shimadzu Corp, Kyoto, Japan) on a reversed phase Shimpak C18 column $(5 \mu \mathrm{m}, 250 \mathrm{~mm}$ $\times 4.6 \mathrm{~mm}$ ). Phenolic content material within the extracts had been detected the usage of octadecylsilyl silica gel as stationary phase. Solvent system consisting of [A] phosphoric acid: water $(0.5: 99.5, \mathrm{v} / \mathrm{v}),[\mathrm{B}]$ acetonitrile was used as mobile phase at a flow rate of $1 \mathrm{ml} / \mathrm{min}$. Phenolic acid standards such as gallic acid, p-coumaric acid, ellagic acid, hydroxy benzoic acid and vanillic acids were employed for identification of phenolic acids present in chloroform and ethanol extracts of Lantana camara by comparing the retention time under similar experimental conditions. The detector used for analysis was UV detector at $220 \mathrm{~nm}$. Flavonoid content within the extracts was detected using octadecylsilyl colloid as stationary phase. Solvent system consisting of methanol, water and orthophosphoric acid (50:49.6:0.4, v/v) was used as mobile phase at a flow of $0.5 \mathrm{ml} / \mathrm{min}$. Rutin, quercetin, myricetin, kaempferol and luteolin were used as references [22, 23].

\section{Statistical Analysis}

Data presented on the average of three replicates as means \pm standard error obtained from independent experiments.

\section{Results}

The crude extracts obtained from the Lantana camara by hot extraction method using different solvents (ethanol and chloroform) gave varied amounts of yield. These crude extracts were in several colours and have characteristic odours.

\section{Antibacterial Activity}

The antibacterial activity of Lantana camara using ethanol and chloroform solvents for crude extraction and they were recorded by measuring inhibition zone in $\mathrm{mm}$.

\section{Antibacterial Activity of Standard Antibiotic Ciprofloxin}

The present study evaluated for antibacterial activity of standard antibiotic ciprofloxin against some pathogenic bacteria by using agar well diffusion method. Inhibition zone shows against the bacteria (Table 1) (Figure 2).

Table 1. Antibacterial activity of standard antibiotic Ciprofloxin

\begin{tabular}{cccc}
\hline \multirow{2}{*}{$\begin{array}{c}\text { Sl. } \\
\text { No. }\end{array}$} & Name of the organisms & \multicolumn{2}{c}{ Inhibition Zone (mm) } \\
\cline { 3 - 4 } & & $\mathbf{1} \boldsymbol{\mu} \mathbf{g} / \mathbf{m L}$ & $\mathbf{1 0} \boldsymbol{\mu} \mathbf{g} \mathbf{m L}$ \\
\hline 1 & Escherichia coli & $16 \pm 1.6$ & $20 \pm 3.4$ \\
2 & Bacillus subtilis & $16 \pm 1.9$ & $21 \pm 4.2$ \\
3 & Xanthomonas sp. & $16 \pm 1.5$ & $17 \pm 2.1$ \\
4 & Pseudomonas aeruginosa & $18 \pm 1.6$ & $20 \pm 3.2$ \\
5 & Bacillus sp. & $18 \pm 2.5$ & $21 \pm 3.3$ \\
6 & Pseudomonas fluorescens & $18 \pm 2.9$ & $21 \pm 3.8$ \\
\hline
\end{tabular}

Note: Results are mean \pm S.E of three replicates $(n=3)$ 


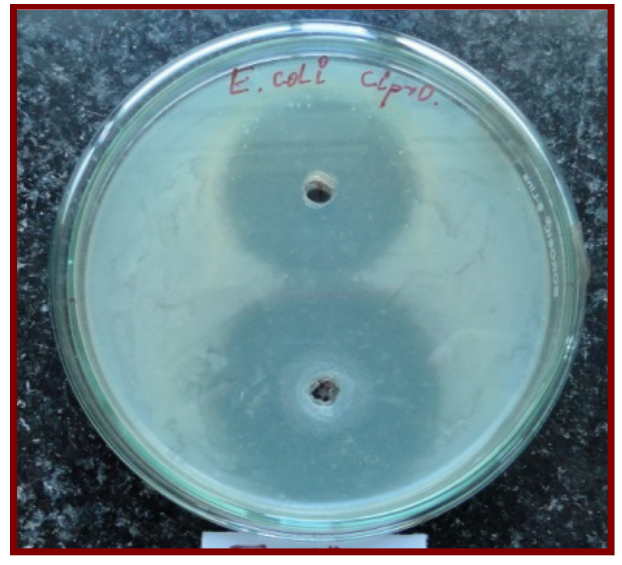

Escherichia coli

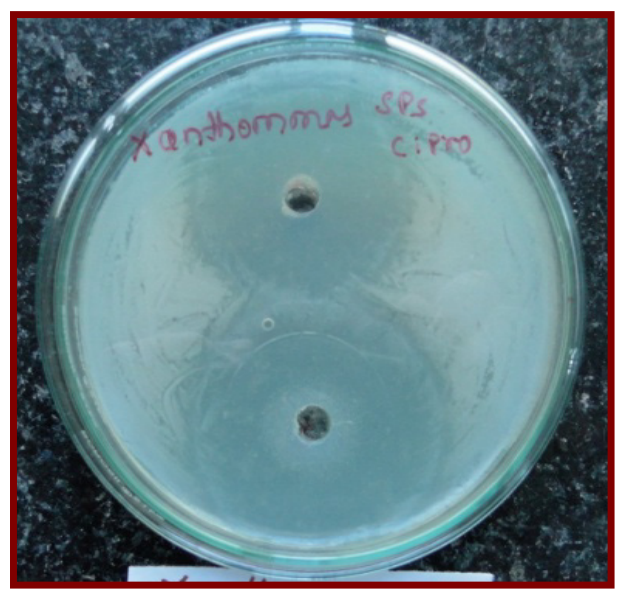

Xanthomonas sp.

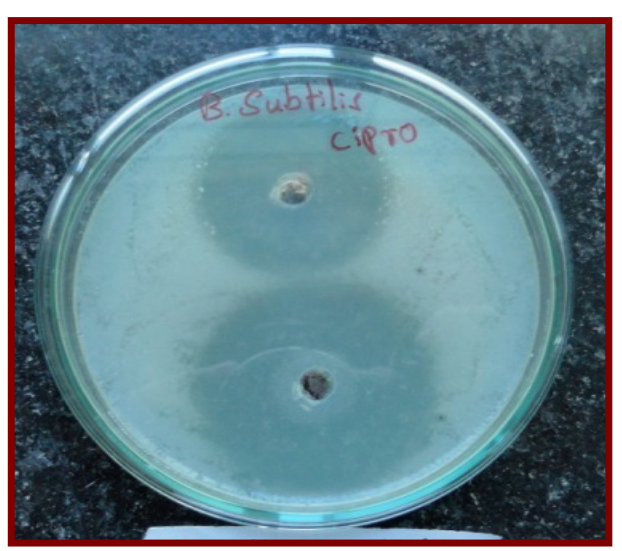

Bacillus subtilis

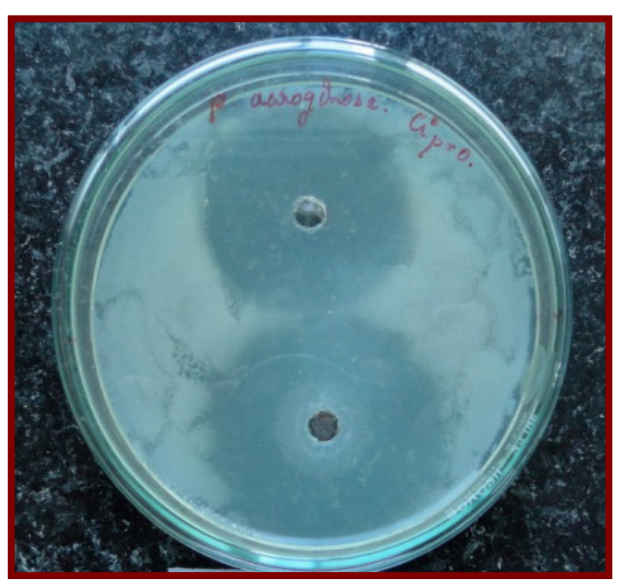

Pseudomonas aeruginosa

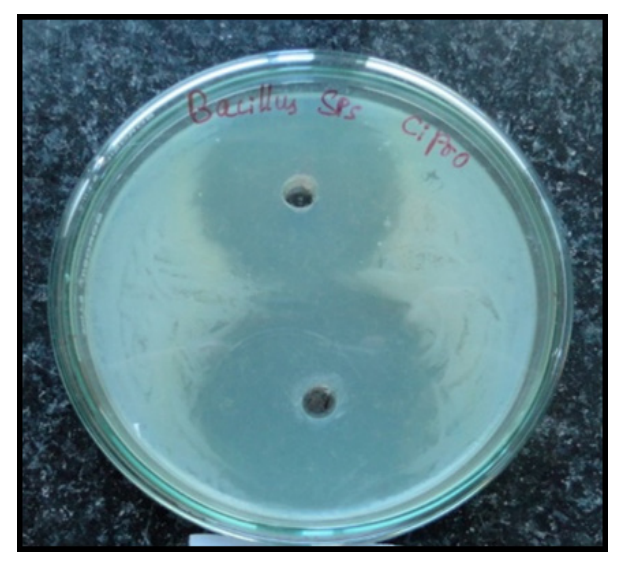

Bacillus sp.

Figure 2. Antibacterial activity of standard antibiotic Ciprofloxin

Table 2. Antibacterial activity of ethanol leaf extract of Lantana camara

\begin{tabular}{|c|c|c|c|c|c|c|}
\hline \multirow{2}{*}{$\begin{array}{l}\text { Sl. } \\
\text { No. }\end{array}$} & \multirow{2}{*}{ Name of the organisms } & \multirow{2}{*}{$\begin{array}{c}\text { MIC } \\
(\mathrm{mg} / \mathrm{mL})\end{array}$} & \multicolumn{4}{|c|}{ Inhibition Zone (mm) } \\
\hline & & & $25 \mathrm{mg} / \mathrm{mL}$ & $50 \mathrm{mg} / \mathrm{mL}$ & $75 \mathrm{mg} / \mathrm{mL}$ & $100 \mathrm{mg} / \mathrm{mL}$ \\
\hline 1 & Escherichia coli & 3 & $4.0 \pm 0.02$ & $4.0 \pm 0.12$ & $3.0 \pm 0.001$ & $3.0 \pm 0.001$ \\
\hline 2 & Bacillus subtilis & 3 & $4.0 \pm 0.01$ & $5.0 \pm 0.05$ & $5.0 \pm 0.02$ & $5.0 \pm 0.09$ \\
\hline 3 & Xanthomonas sp. & 2 & $6.0 \pm 0.10$ & $6.0 \pm 0.01$ & $4.0 \pm 0.05$ & $4.0 \pm 0.01$ \\
\hline 4 & Pseudomonas aeruginosa & 3 & $3.0 \pm 0.008$ & $4.0 \pm 0.08$ & $4.0 \pm 0.08$ & $4.0 \pm 0.02$ \\
\hline 5 & Bacillus sp. & 3 & $3.0 \pm 0.004$ & $3.0 \pm 0.03$ & $4.0 \pm 0.10$ & $4.0 \pm 0.06$ \\
\hline 6 & Pseudomonas fluorescens & 2 & $2.0 \pm 0.01$ & $2.0 \pm 0.09$ & $2.0 \pm 0.01$ & $2.0 \pm 0.01$ \\
\hline
\end{tabular}

Note: Results are mean \pm S.E of three replicates $(n=3)$ 
Antibacterial Activity of Ethanol Leaf Extract of Lantana camara

The present study was evaluated for antimicrobial activity of ethanol leaves extract against some pathogenic bacteria and fungi by using agar well diffusion method. The minimal inhibitory concentration (MIC) ranges to some bacteria from $2 \mathrm{mg} / \mathrm{mL}$ to $3 \mathrm{mg} / \mathrm{mL}$. The maximum inhibition zone shows against Xanthomonas sp. $(6.0 \pm 0.01$ $\mathrm{mm})$, Bacillus subtilis $(5.0 \pm 0.05 \mathrm{~mm})$, Pseudomonas aeruginosa $(4.0 \pm 0.08 \mathrm{~mm})$, Escherichia coli $(4.0 \pm 0.02$ $\mathrm{mm})$, Bacillus sp $(4.0 \pm 0.06 \mathrm{~mm})$ and the minimum inhibition zone shows against, Pseudomonas fluorescens $(2.0 \pm 0.01 \mathrm{~mm})$ (Table 2), (Figure 3).

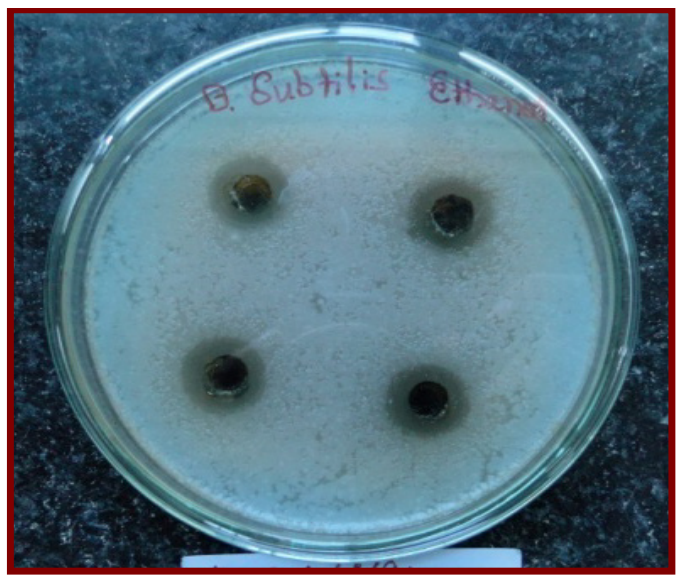

Bacillus subtilis

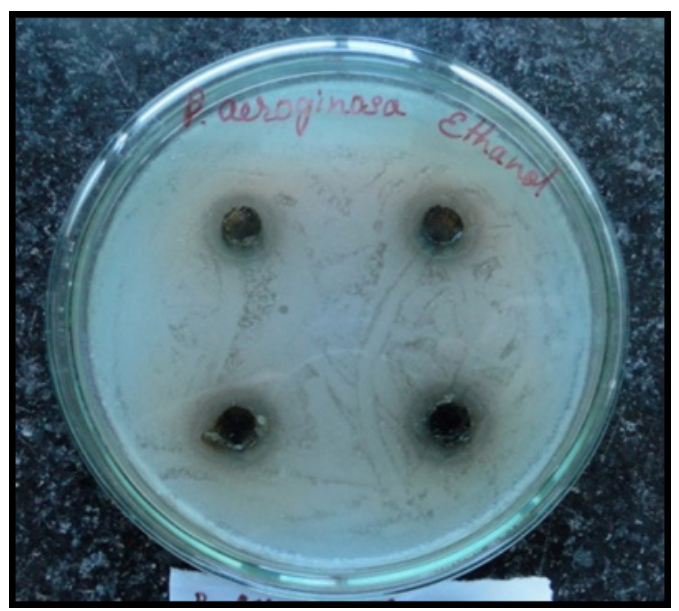

Pseudomonas aeruginosa

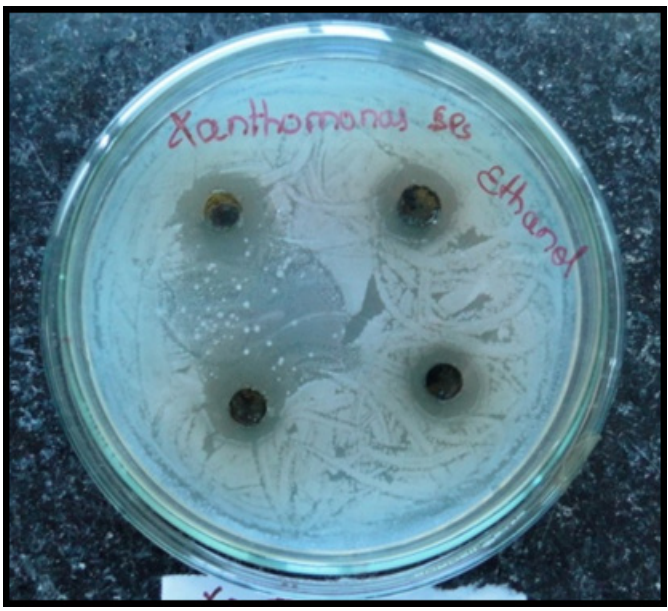

Xanthomonas sp.

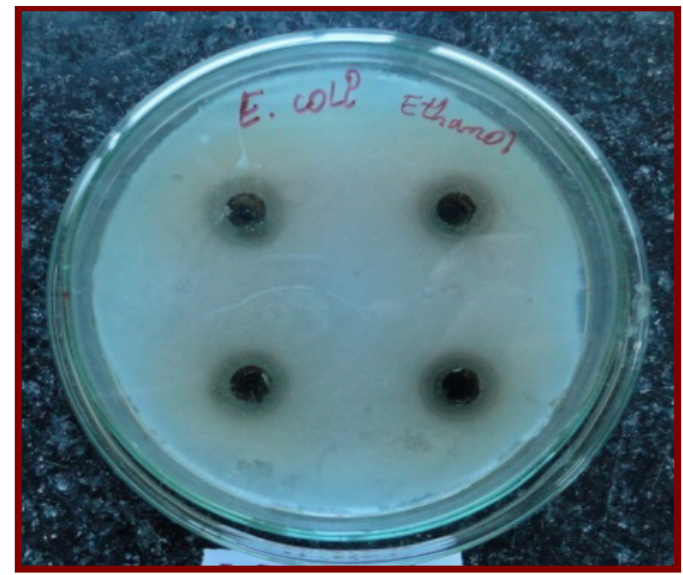

Escherichia coli

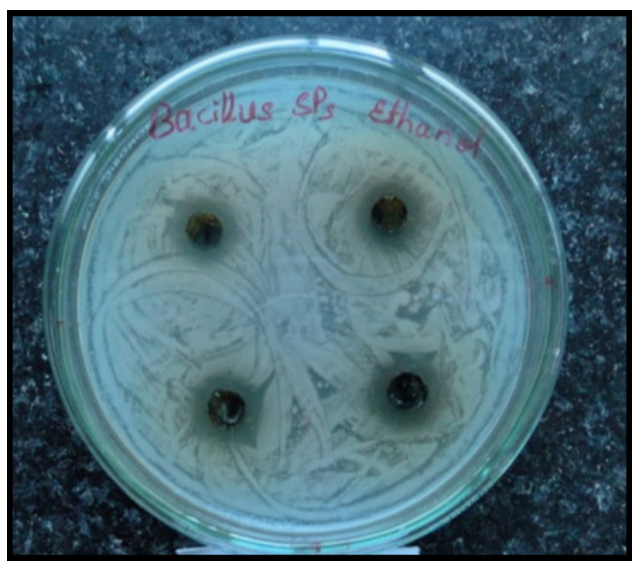

Bacillus sp.

Figure 3. Antibacterial activity of ethanolic leaf extract of Lantana camara 
Antibacterial Activity of Chloroform Leaf Extract of Lantana camara

In the current study, evaluated for antimicrobial activity of chloroform leaves extract against some pathogenic bacteria and fungi by using agar well diffusion method. The minimal inhibitory concentration (MIC) ranges to some bacteria from $2 \mathrm{mg} / \mathrm{mL}$ to $3 \mathrm{mg} / \mathrm{mL}$. The maximum inhibition zone shows against Escherichia coli $(4.0 \pm 0.20$ $\mathrm{mm})$, Bacillus sp. $(3.0 \pm 0.07 \mathrm{~mm})$, Pseudomonas aeruginosa $(3.0 \pm 0.08 \mathrm{~mm})$, Bacillus subtilis $(3.0 \pm 0.19$ $\mathrm{mm})$, Xanthomonas sp. $(2.0 \pm 0.21 \mathrm{~mm})$ and the minimum inhibition zone shows against, Pseudomonas fluorescens $(1.0 \pm 0.02 \mathrm{~mm})$ (Table 3).

Antifungal Activity of Standard Antifungal Agent Flucanozole

The present study was evaluated for antifungal activity of standard antifungal agent Flucanozole. It shows inhibition zone (mm) against pathogenic fungi (Table 4) (Figure 4).

Antifungal Activity of Ethanol and Chloroform Leaf Extract of Lantana camara

The present study was undertaken to determine the antifungal activity of ethanol and chloroform extracts were recorded by measuring inhibition zone in $\mathrm{mm}$. But there

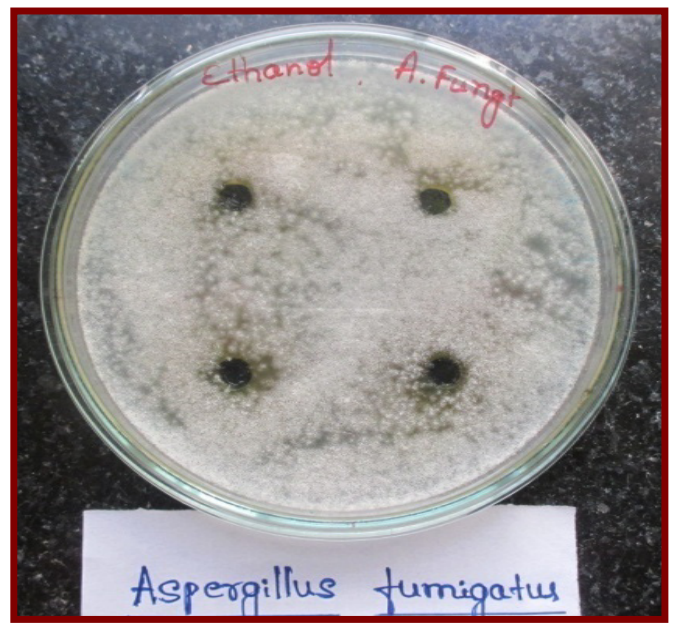

$\mathrm{AF}$

Note: AF- Aspergillus fumigatus, AT- Aspergillus terreus

Figure 5. Antifungal activity of ethanolic leaf extract of Lantana camara

Table 3. Antibacterial activity of chloroform leaf extract of Lantana camara

\begin{tabular}{|c|c|c|c|c|c|c|}
\hline \multirow{2}{*}{$\begin{array}{l}\text { SI. } \\
\text { No. }\end{array}$} & \multirow{2}{*}{ Name of the organisms } & \multirow{2}{*}{$\underset{(\mathrm{mg} / \mathrm{mL})}{\mathrm{MIC}}$} & \multicolumn{4}{|c|}{ Inhibition Zone (mm) } \\
\hline & & & $25 \mathrm{mg} / \mathrm{mL}$ & $50 \mathrm{mg} / \mathrm{mL}$ & $75 \mathrm{mg} / \mathrm{mL}$ & $100 \mathrm{mg} / \mathrm{mL}$ \\
\hline 1 & Escherichia coli & 3 & $2.0 \pm 0.01$ & $2.0 \pm 0.002$ & $4.0 \pm 0.20$ & $4.0 \pm 0.22$ \\
\hline 2 & Bacillus subtilis & 3 & $3.0 \pm 0.01$ & $3.0 \pm 0.001$ & $3.0 \pm 0.31$ & $3.0 \pm 0.19$ \\
\hline 3 & Xanthomonas sp. & 2 & $2.0 \pm 0.04$ & $2.0 \pm 0.01$ & $2.0 \pm 0.03$ & $2.0 \pm 0.21$ \\
\hline 4 & Pseudomonas aeruginosa & 2 & $2.0 \pm 0.05$ & $2.0 \pm 0.003$ & $2.0 \pm 0.04$ & $3.0 \pm 0.08$ \\
\hline 5 & Bacillus sp. & 2 & $3.0 \pm 0.01$ & $2.0 \pm 0.002$ & $3.0 \pm 0.09$ & $3.0 \pm 0.07$ \\
\hline 6 & Pseudomonasfluorescens & 2 & $1.0 \pm 0.02$ & $1.0 \pm 0.001$ & $2.0 \pm 0.01$ & $2.0 \pm 0.04$ \\
\hline
\end{tabular}

Note: Results are mean \pm S.E of three replicates $(n=3)$

was no such an antifungal activity. Both solvents ethanol and chloroform leaf extracts fail to inhibit the pathogenic fungal organisms (Table 5 and 6) (Figure 5 and 6).

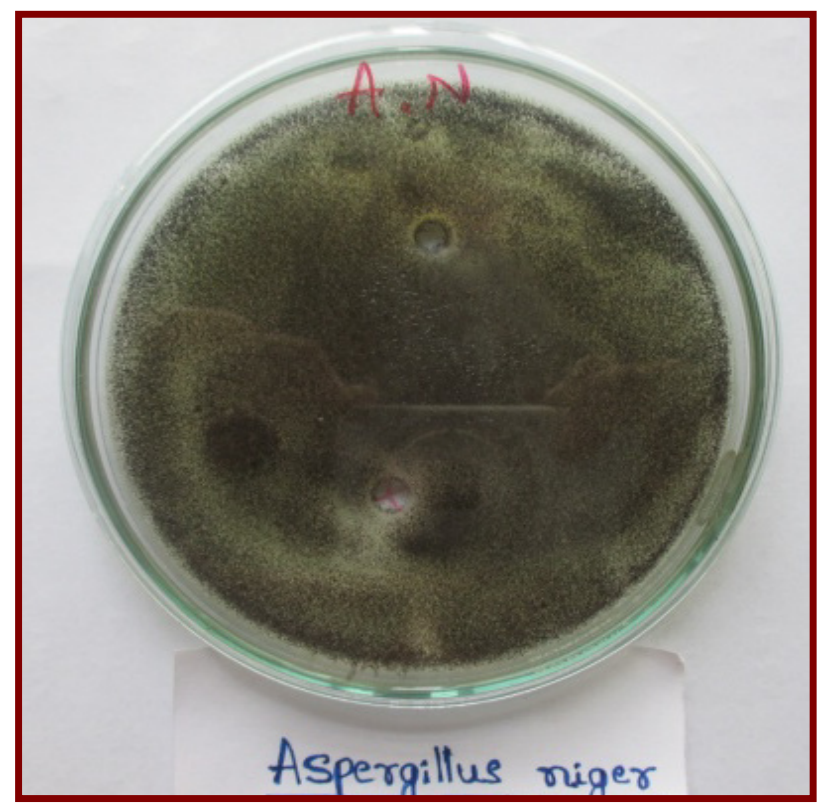

AN

Figure 4. Antifungal activity of standard antifungal agent Flucanozole

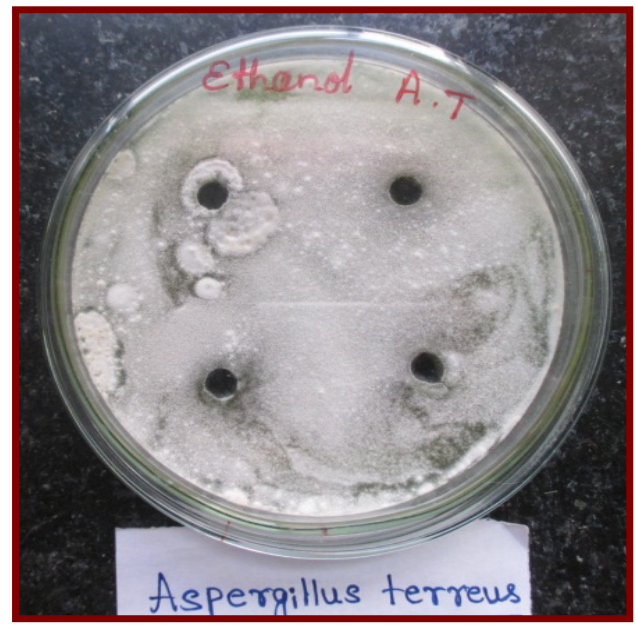

AT

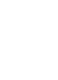


Table 4. Antifungal activity of standard antibiotic agent flucanozole

\begin{tabular}{cccc}
\hline \multirow{2}{*}{ Sl. No. } & Name of the organisms & \multicolumn{2}{c}{ Inhibition Zone (mm) } \\
\cline { 3 - 4 } & Aspergillus fumigatus & $\mathbf{1} \boldsymbol{\mu g} / \mathbf{m L}$ & $\mathbf{1 0} \boldsymbol{\mu g} / \mathbf{m L}$ \\
2 & Aspergillus niger & $1.0 \pm 0.02$ & $2.0 \pm 0.01$ \\
3 & Aspergillus terreus & -- & -- \\
4 & Aspergillus flavus & -- & - \\
5 & Aspergillus sp. & $1.0 \pm 0.04$ & $2.0 \pm 0.08$ \\
6 & Fusarium oxysporum & $2.0 \pm 0.06$ & $3.0 \pm 0.10$ \\
\hline
\end{tabular}

Note: Results are mean \pm S.E of three replicates $(n=3)$

Table 5. Antifungal activity of ethanol leaf extract of Lantana camara

\begin{tabular}{|c|c|c|c|c|c|c|}
\hline \multirow{2}{*}{$\begin{array}{c}\text { Sl. } \\
\text { No. }\end{array}$} & \multirow{2}{*}{ Name of the organisms } & \multirow{2}{*}{$\underset{\mathrm{mg} / \mathrm{mL}}{\mathrm{MIC}}$} & \multicolumn{4}{|c|}{ Inhibition Zone (mm) } \\
\hline & & & $25 \mathrm{mg} / \mathrm{mL}$ & $50 \mathrm{mg} / \mathrm{mL}$ & $75 \mathrm{mg} / \mathrm{mL}$ & $100 \mathrm{mg} / \mathrm{mL}$ \\
\hline 1 & Aspergillus fumigatus & Nil & $1.0 \pm 0.01$ & $2.0 \pm 0.02$ & $2.0 \pm 0.01$ & $2.0 \pm 0.03$ \\
\hline 2 & Aspergillus niger & Nil & -- & -- & -- & -- \\
\hline 3 & Aspergillus terreus & Nil & -- & -- & -- & -- \\
\hline 4 & Aspergillus flavus & Nil & $1.0 \pm 0.03$ & $2.0 \pm 0.02$ & $2.0 \pm 0.06$ & $2.0 \pm 0.04$ \\
\hline 5 & Aspergillus sp. & Nil & $2.0 \pm 0.04$ & $3.0 \pm 0.10$ & $3.0 \pm 0.08$ & $3.0 \pm 0.01$ \\
\hline 6 & Fusarium oxysporum & Nil & -- & -- & $2.0 \pm 0.07$ & $3.0 \pm 0.03$ \\
\hline
\end{tabular}

Note: Results are mean \pm S.E of three replicates $(n=3)$

Table 6. Antifungal activity of chloroform leaf extract of Lantana camara

\begin{tabular}{|c|c|c|c|c|c|c|}
\hline \multirow{2}{*}{$\begin{array}{l}\text { Sl. } \\
\text { No. }\end{array}$} & \multirow{2}{*}{ Name of the organisms } & \multirow{2}{*}{$\begin{array}{c}\mathrm{MIC} \\
\mathrm{mg} / \mathrm{mL}\end{array}$} & \multicolumn{4}{|c|}{ Inhibition Zone (mm) } \\
\hline & & & $25 \mathrm{mg} / \mathrm{mL}$ & $50 \mathrm{mg} / \mathrm{mL}$ & $75 \mathrm{mg} / \mathrm{mL}$ & $100 \mathrm{mg} / \mathrm{mL}$ \\
\hline 1 & Aspergillus fumigatus & Nil & $1.0 \pm 0.01$ & $2.0 \pm 0.001$ & $2.0 \pm 0.01$ & $2.0 \pm 0.02$ \\
\hline 2 & Aspergillus niger & Nil & -- & -- & -- & -- \\
\hline 3 & Aspergillus terreus & Nil & -- & -- & -- & -- \\
\hline 4 & Aspergillus flavus & Nil & $1.0 \pm 0.02$ & $2.0 \pm 0.01$ & $2.0 \pm 0.02$ & $2.0 \pm 0.02$ \\
\hline 5 & Aspergillus sp. & Nil & $2.0 \pm 0.04$ & $3.0 \pm 0.06$ & $3.0 \pm 0.08$ & $3.0 \pm 0.10$ \\
\hline 6 & Fusarium oxysporum & Nil & -- & -- & $3.0 \pm 0.09$ & $3.0 \pm 0.20$ \\
\hline
\end{tabular}

Note: Results are mean \pm S.E of three replicates $(n=3)$

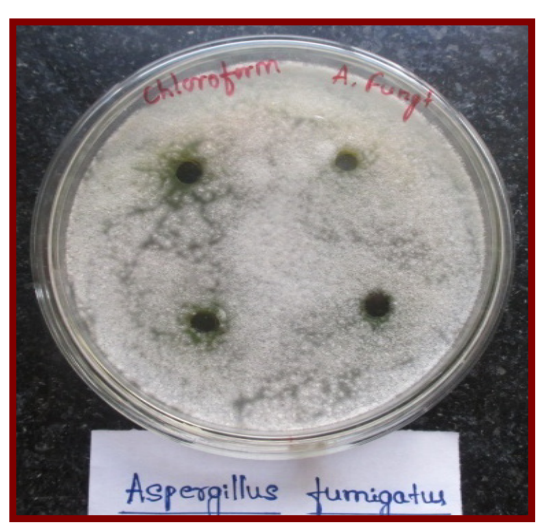

AF

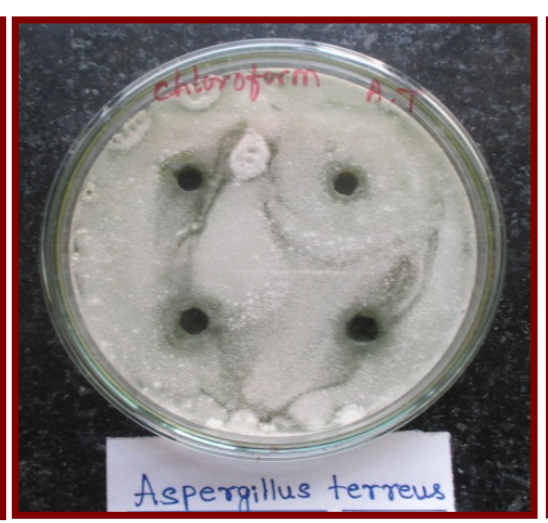

AT

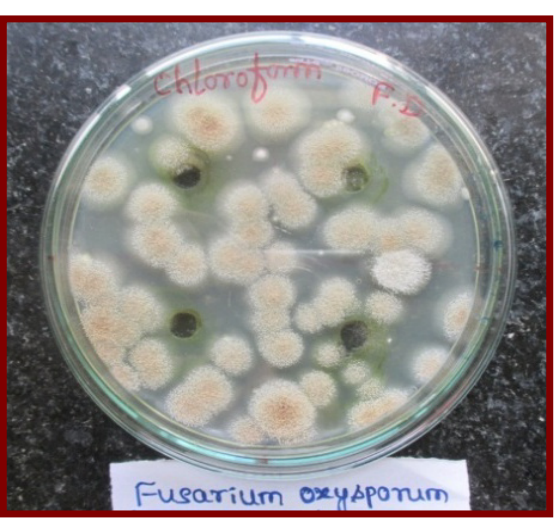

FO

Note: AF- Aspergillus fumigatus, AT- Aspergillus terreus, FO- Fusarium oxysporum

Figure 6. Antifungal activity of Chloroform leaf extract of Lantana camara 


\section{High Performance Liquid Chromatography (HPLC) - UV analysis}

HPLC was employed to characterize the phenolic acids and flavonoids present in chloroform and ethanol extracts. HPLC analysis of Lantana camara (leaves) chloroform extract revealed the presence of gallic acid with retention time of 1.54 (Figure 7a). The HPLC-UV spectral peaks of chloroform extract of Lantana camara (Figure 7b) showed the peaks for presence of flavonoid compounds, quercetin at $350 \mathrm{~nm}$ with the analysis of retention time of standard flavonoids.

HPLC reports indicated that the ethanol extract contains gallic acid with retention time of $1.54 \mathrm{~min}$ (Figure 7c). The HPLC-UV spectral peaks of ethanol extract revealed the presence of quercetin, myricetin and one unknown flavonoid (Figure 7d). The quantitative analysis flavonoids by HPLC analysis was shown in the Table 7 .

Table 7. Quantitative estimation of chloroform and ethanol extracts for phenolic acids and flavonoids by HPLC method

\begin{tabular}{cccc}
\hline Phenolic acids and flavonoids & $\begin{array}{c}\text { Chloroform } \\
\text { extract }(\mathbf{m g} / \mathbf{g})\end{array}$ & $\begin{array}{c}\text { Ethanol } \\
\text { extract } \\
\text { (mg/g) }\end{array}$ \\
\hline \multirow{4}{*}{$\begin{array}{c}\text { Gallic acid } \\
\text { acids }\end{array}$} & 91.49 & 219.0 \\
& Coumaric acid & - & - \\
& $\begin{array}{c}\text { Ellagic acid } \\
\text { Hydroxybenzoic } \\
\text { acid }\end{array}$ & - & - \\
& Vanillic acid & - & - \\
& Rutin & - & - \\
& Quercetin & 104.7 & 109.3 \\
Flavonoids & Myricetin & - & 63.5 \\
& Kaempferol & - & - \\
& Luteolin & - & - \\
\hline
\end{tabular}

\section{Discussion}

Lantana camara great and various distributions is a mirrored image of its extensive ecological tolerances. The species takes place in numerous habitats starting from open unshaded areas which consist of wastelands, rainforest edges, beachfronts, and forests disturbed through sports consisting of hearth place or logging [24, 25]. The species also thrive well in disturbed area which includes roadside, railway tracks and canals. Anthropogenic activity further aggravates the invasion and allows it to spread [26, 27].

Lantana camara extract was not very active against strains of bacteria. A range of zone of inhibition 12-12.3 $\mathrm{mm}$ was observed against Micrococcus luteus, E. coli and Klebsiella pneumoniae. A indicate zone of inhibition ten millimetre was showed against Salmonella setubal and
Staphylococcus aureus. Entarobacter aerogenase showed little zone of inhibition (9 mm) [28-30]. Sharama et al., [10] reported presence of Emodin and Physcion in L. camara extract that showed mild activities against different bacterial strains. An antibacterial activity of different Lantana species has been evaluated [31] and it is found that Lantana species have good antibacterial agents. $S$. angustifolia did not showed activity beside any bacterial strain tested.

The present study, involved various pharmacological activities of leaves of Lantana camara. The dried and powdered leaf material was extracted with ethanol and chloroform solvents. The extract was investigated for phytoconstituents, antibacterial and antifungal activity. The extract was subjected to HPLC (High Performance Liquid Chromatography) to find out the presence of phytoconstituents like phenols and flavonoids.

The standard antibiotic ciprofloxin showed inhibition zone against all the tested pathogenic bacteria and fluconazole showed inhibition zone against all the tested pathogenic fungi. In this work, the antibacterial activity of extract was determined by using agar well diffusion method against few pathogenic bacteria. In this study, marked the inhibitions of test bacteria were observed. Among bacteria, Xanthomonas sp. was found to be more sensitive to ethanol extract and Bacillus subtilis was found to be more sensitive to chloroform extract. The antifungal activity of Lantana camara leaf extracts were determined using agar well diffusion method against certain pathogenic fungi. In this study, there was no such marked inhibition showed for all fungi.

Similar to this work, Suthar and Sharma, [32] work suggested that oils obtained from Lantana camara caused a significant inhibition on fungal growth, as compared to controls. In the primary days of assessment the oil of $L$. camara at an attention of one thousand $\mathrm{mg} / \mathrm{L}$ brought about a discount with inside the increase of the fungal colonies of $25.0 \%$ and $19.6 \%$, respectively. At higher concentrations the fungus growth was completely inhibited during the first day and for $10000 \mathrm{mg} / \mathrm{L}$ a full inhibition was still observed during the second day.

Misra et al., [33] studied the consequences of hydroalcoholic extract from Lantana camara var. aculeata leaves on fertility, popular reproductive overall performance and teratology within side the rat. The statistics confirmed that the extract interfered with inside the frequency of fetal skeleton anomalies from dams handled with the extract and prompted embryo toxicity as indicated with the aid of using post-implantation loss, with none symptoms and symptoms of maternal toxicity. The different parameters evaluated did now no longer endorse modifications. 


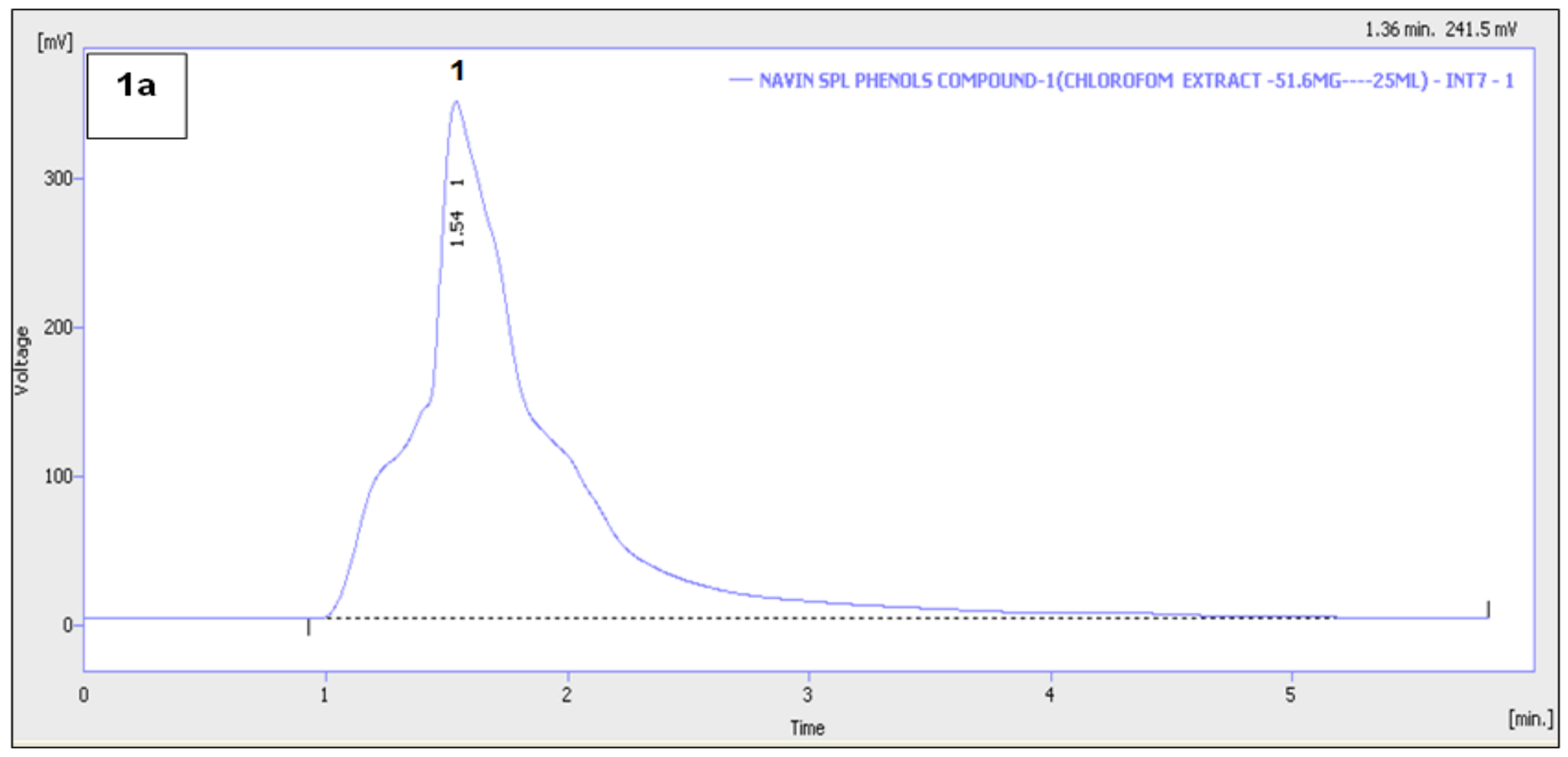

Figure 7a. HPLC chromatogram of phenolic acids of chloroform extracts (1- Gallic acid) 


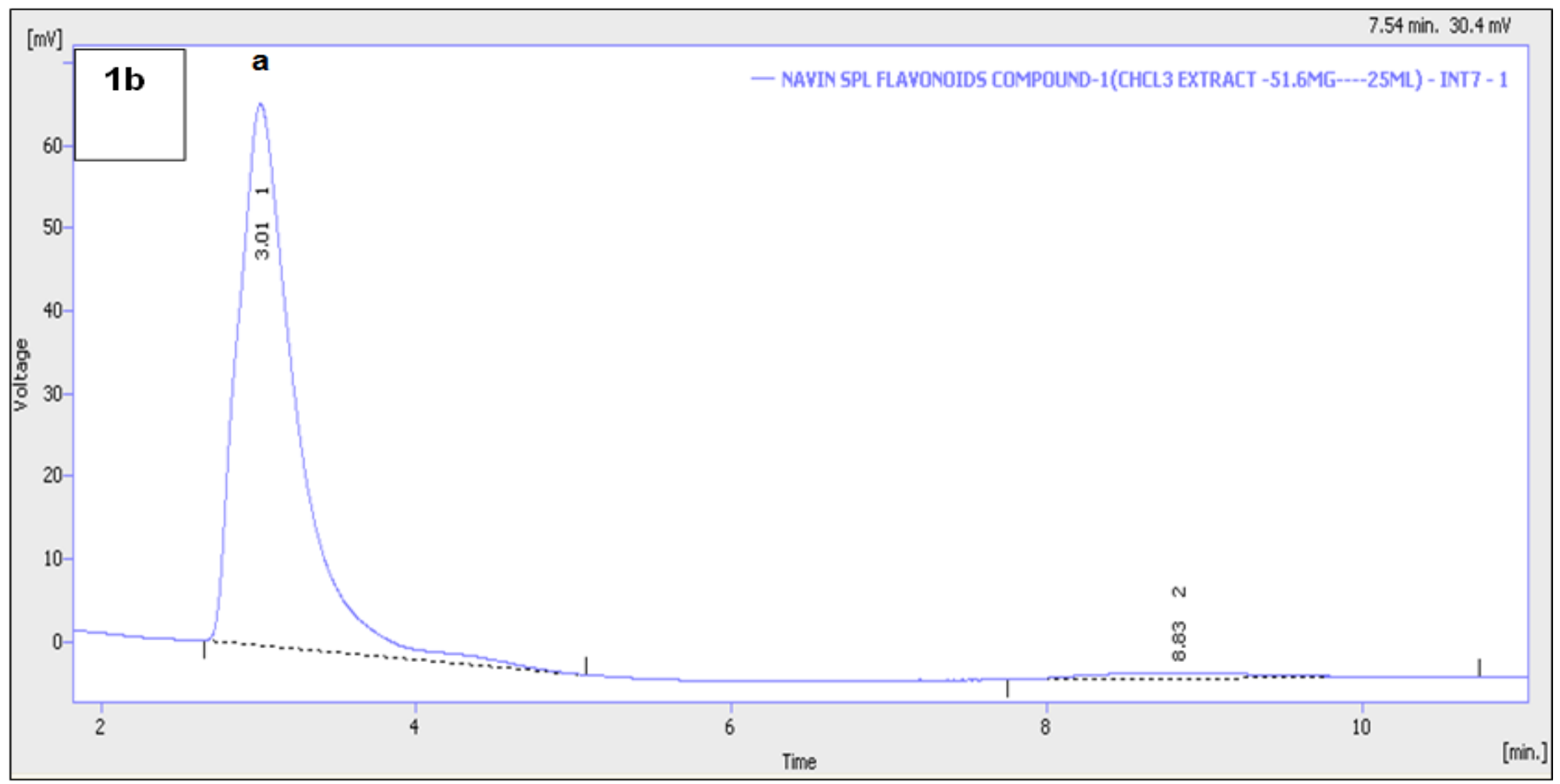

Figure 7b. HPLC chromatogram of flavonoids of chloroform extracts (a- Quercetin) 


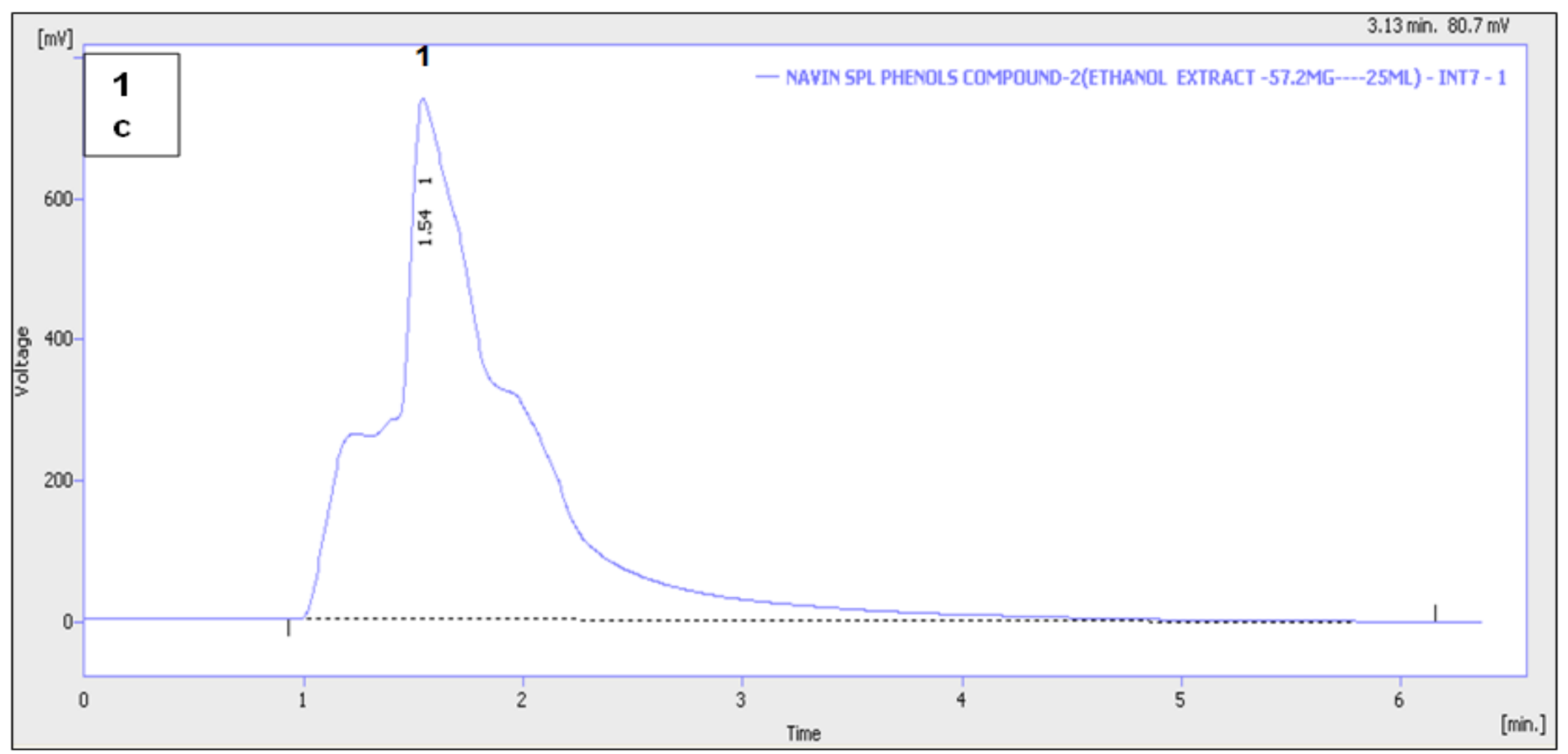

Figure 7c. HPLC chromatograms of phenolic acids of ethanol extract (1- Gallic acid) 


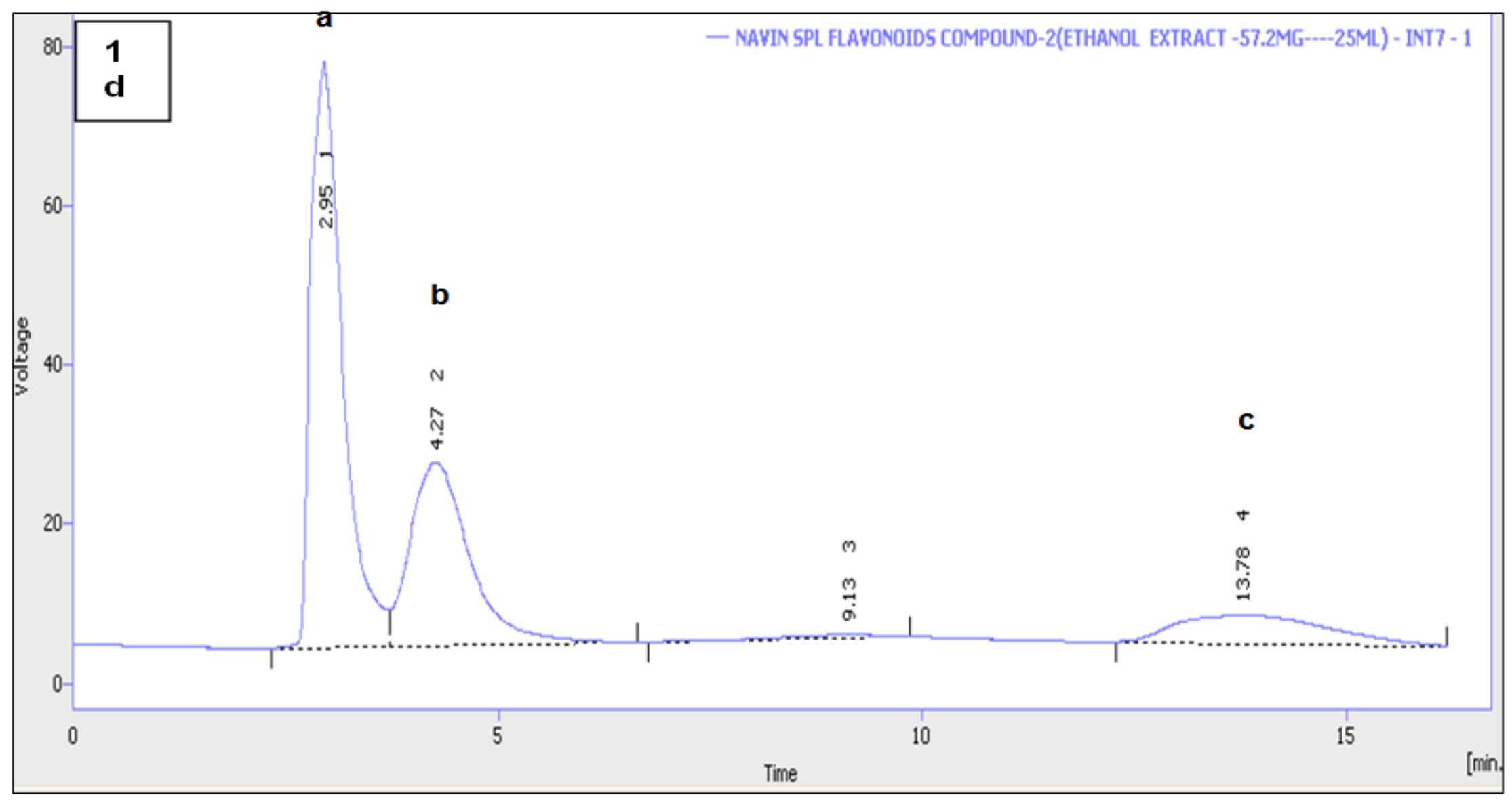

Figure 7d. HPLC chromatograms of flavonoids of ethanol extract (a- Quercetin, b- Myricetin, c-Unkonown) 
In the current study, HPLC was employed to characterize the phenolic acids and flavonoids present in chloroform and ethanol extracts. Bacterial infections essentially talk to any sort of contamination this is initiated with the aid of using a specific form of bacterium or micro organism. Most bacterial infections in people are as a result of a set of micro organism called mesophilic micro organism, E. coli. Bacteria like P. aeruginosa and E. coli cause infections like nosocomial infections, food borne illness, gastrointestinal infections, wound infections etc.

The extracts of Lantana camara var. aculeata leaves had been studied for his or her phytochemical materials and termiticidal results towards grownup termite workers. The $5 \%$ chloroform extract was found to be significantly effective against termite workers [34, 35]. The antimicrobial efficacy of flavonoids (free and bound) and crude alkaloids of Lantana camara was determined by disc diffusion assay against three bacteria (Escherichia coli, Proteus mirabilis, and Staphylococcus aureus) and two fungi (Candida albicans and Trichophyton mentagrophytes) $[36,37]$.

$S$. aureus is the same old pathogen, even though publicity to Pseudomonas aeruginosa in warm tubs or swimming pools can result in folliculitis. Folliculitis is a superficial contamination of the hair follicles characterised through erythematous, follicular-primarily based totally papules and pustules. Furuncles are deeper infections of the hair follicle characterized by inflammatory nodules with pustular drainage, which can coalesce to form larger draining nodules and many skin infections are caused due to the fungal organisms [38-40].

Thus bacterial and fungal infections can be cured by some of these types of plant extracts by suppressing those pathogens without any side effects.

\section{Conclusion}

The present study, involved various pharmacological activities of leaves of Lantana camara. The dried and powdered leaf material was extracted with ethanol and chloroform solvents. The extract was investigated for phytoconstituents, antibacterial and antifungal activity. The extract was subjected to HPLC to find out the presence of phytoconstituents like phenols and flavonoids. The antibacterial activity of extract was determined by using agar well diffusion method against few pathogenic bacteria. Among bacteria, Xanthomonas sp. was found to be more sensitive to ethanol extract and Bacillus subtilis was found to be more sensitive to chloroform extract. The antifungal activity of Lantana camara leaf extracts were determined using agar well diffusion method against certain pathogenic fungi. In this study, there was no such marked inhibition showed for all fungi. HPLC was employed to characterize the phenolic acids and flavonoids present in chloroform and ethanol extracts. Thus bacterial and fungal infections can be cured by some of these types of plant extracts by suppressing those pathogens without any side effects.

\section{Acknowledgements}

The authors are thankfully acknowledged to the Department of Microbiology, Kuvempu University, Shivamogga, and Karnataka for providing laboratory facilities. They are grateful to their relatives and associates for their good wishes for the success of this work.

\section{REFERENCES}

[1] Shanab A.B., Adwan G., Jarrar N., Hijleh A.A., Adwan K., "Antibacterial activity of four plant extracts used in Palestine in folkloric medicine against Methicillin-resistant Staphylococcus aureus", Turkish Journal of Biology, Vol. 30, no. 4, pp. 195-198, 2006.

[2] Barreto F.S., Sousa E.O., Campos A.R., Costa J.G.R., Rodrigues E.F.G., "Antibacterial Activity of Lantana camara Linn and Lantana montevidensis Brig Extracts from Cariri-Ceara, Brazil", Journal of Young Pharmacists, Vol. 2, no. 1, pp. 42-44, 2010. DOI: 10.4103/0975-1483.6 2211.

[3] MdeeL. K., Masoko P., Eloff J.N., "The activity of extracts of seven common invasive plant species on fungal phyto-pathogens", South African Journal of Botany, Vol. 75, no. 2, pp. 375-379, 2009. DOI: org/10.1016/j.sajb.2009.02.003.

[4] Naz R., Bano A., "Phytochemical screening, antioxidants and antimicrobial potential of Lantana camara in different solvents", Asian Pacific Journal of Tropical Disease, Vol. 3, no. 6, pp. 480-486, 2013. DOI: 10.1016/S2222-1808(13)60104-8.

[5] Cushnie T.P., Andrew J., Lamb N., “Antimicrobial activity of flavonoids",International Journal of Antimicrobial Agents, Vol. 26, no. 5, pp. 343-356, 2005. DOI: org/10.1016/j.ijantimicag.2005.09.002.

[6] Dubey D., PadhyR.N., "Antibacterial activity of Lantana camara L. against multidrug resistant pathogens from ICU patients of a teaching hospital", Journal of Herbal Medicine, Vol. 3, no. 2, pp. 65-75, 2013. DOI: org/10.1016/j.hermed.2012.12.002.

[7] Eloff J.N., Mdee L.K., Masoko, P., "Invasive and weedy species can be used as a source of antifungal compounds to control plant fungal pathogens", South African Journal of Botany, Vol. 73, no. 2, pp. 287-294, 2007. DOI:10.1016/j.sajb.2007.02.041.

[8] Moshi M.J., Mbwambo Z.H., "Some pharmacological properties of extracts of Terminalia sericea roots", Journal of Ethnopharmacology, Vol. 97, no.1, pp. 43-55, 2005. DOI: $10.1016 /$ j.jep.2004.09.056.

[9] Satish S., Raveesh K.A., Janardhna G.R., "Antibacterial activity of plant extracts on phytopathogenic Xanthomonas campestris pathovars", Letters in Applied Microbiology, 
Vol. 28, no. 2, pp. 145-147, 1999. DOI: org/10.1046/j.136 5-2672.1999.00479.x.

[10] Sharma O.P., Makkar H.P.S., Dawra R.K., "A review of the noxious plant Lantana camara", Toxicon- Journal, Vol. 26, no. 11 , pp. $975-987,1988$. DOI: org/10.1016/0041-0101 (88)90196-1.

[11] Bevilacqua A.H.V., Suffredini I.B., Romoff P., Lago J.H.G., Bernardi M.M., "Toxicity of apolar and polar Lantana camara crude extracts in mice", Research in Veterinary Science, Vol. 90, no. 1, pp.106-115, 2011. DOI: 10.1016/j.rvsc.2010.05.001.

[12] Oyourou J.N., Combrinck S., Regnier T., Marston A., "Purification, stability and antifungal activity of verbascoside from Lippiajavanica and Lantana camara leaf extracts", Industrial Crops and Products, Vol. 43, no. 820 826, 2013. DOI: org/10.1016/j.indcrop.2012.08.028.

[13] Begum S, Wahab A, Siddiqui B.S., "Pentacyclic triterpenoids from the aerial parts of Lantana camara". Chemical and Pharmaceutical Bulletin, 2000; 51: 134-137.

[14] Magassouba F.B., Diallo A., Kouyate M., "Ethnobotanical survey and antibacterial activity of some plants used in Guinean traditional medicine", Journal of Ethnopharmacology, Vol. 114, no. 1, pp. 44-53, 2007. DOI: 10.1016/j.jep.2007.07.009.

[15] Sanjeeb K., Gaurav K., Loganathan K., Kokati V.B.R., “A Review on Medicinal Properties of Lantana camara Linn", Research Journal of Pharmacy and Technology, Vol. 5, no. 6, pp. 711-715, 2012.

[16] Mello F.B., Jacobus D., Carvalho K., "Effects of Lantana camara (Verbenaceae) on general reproductive performance and teratology in rats", Toxicology, Vol. 45, no. 4, pp. 459-466, 2005. DOI: 10.1016/j.toxicon.2004.12. 004 .

[17] Rajashekar Y., Kumar H.V., Kothapalli V.R., Bakthavatsalam N., "Isolation and characterization of biofumigant from leaves of Lantana camara for control of stored grain insect pests", Industrial Crops and Products, Vol. 51, pp. 224-228, 2013. DOI: org/10.1016/j.indcrop.2013.09.006.

[18] Rizvi Z.F., Mukhtar R., Chaudhary M.F., Zia M., "Antibacterial and Antifungal Activities ofLawsoniainerm is, Lantana camara and Swertiaangustifolia", Pakistan Journal of Botany, Vol. 45, no. 1, pp. 275-278, 2013.

[19] Leite S.P., Vieira J.R.C., Medeiros P.L., Leite R.M.P., Lima V.L.M., Xavier H.S., Lima E.O., "Antimicrobial Activity of Indigoferasuffruticosa", Evidence-Based Complementary and Alternative Medicine, Vol. 3, no. 2, pp. 261-265, 2006. DOI: $10.1093 /$ ecam/nel010.

[20] Mazumder A., Saha B.P., Basu S.P., Mazumder R., “A comparison of in vitro antifungal activity of the Methanol extract of various parts of Lagerstroemia parviflora (Roxb)", Ethiopian Pharmaceutical Journal, Vol. 22, no. 1, pp. 61-65, 2005. DOI:10.4314/epj.v22i1.35084.

[21] Pradhan R.R., Hati D.K., Samal S., "Pharmacognostical, phytochemical and antimicrobial studies on the leaves of Lantana camaraLinn”, Der Pharmacia Lettre, Vol. 4, no. 6, pp. 1648-1656, 2012.

[22] Kumar M.S., Maneemegalai S., "Evaluation of Larvicidal
Effect of Lantana Camara Linn against mosquito species Aedesaegypti and Culex quinquefasciatus", Advances in Biological Research, Vol. 2, no. 3-4, pp. 39-43, 2008.

[23] Dua V.K., Pandey A.C., Dash A.P., "Adulticidal activity of essential oil of Lantana camaraleaves against mosquitoes", Indian Journal of Medical Research, Vol. 131, no. 3, pp. 434-439, 2010.

[24] Aadil M., Nitesh S., Sharad K. D., Tarun K.T., Noam A.S., Narayan D., Anirudh K., "Phytochemical characterization and assessment of crude extracts from Lantana camara L. for antioxidant and antimicrobial activity", Frontiers in Agronomy, pp. 1-14, 2012. DOI:org/10.3389/fagro.2020.5 82268 .

[25] Passos J.L., Barbosa L.C., Demuner A.J., Alvarenga E.S., Silva C.M., Barreto R.W., "Chemical characterization of volatile compounds of Lantana camara L. and L. radula and their antifungal activity", Molecules, Vol. 17, no. 10, pp. 11447-11455, 2012. DOI: 10.3390/molecules1710114 47.

[26] Sharma B., Kumar P., "Bioefficacy of Lantana camaraL. against Some Human Pathogens", Indian Journal of Pharmaceutical Sciences, Vol. 71, no. 5, pp. 589-593, 2009. DOI: $10.4103 / 0250-474 X .58177$.

[27] Verma R.K., Verma S.K., "Phytochemical and termiticidal study of Lantana camara var. aculeata leaves", Journal of Fitoterapia, Vol. 77, no. 6, pp. 466-468, 2006. DOI: org/10.1016/j.fitote. 2006.05.014.

[28] Sharma G.P., Raghubanshi A.S., Singh J.S., "Lantana invasion: An overview", Weed Biology and Management, Vol. 5, no. 4, pp. 157-165, 2005. DOI:10.1111/j.1445-666 $4.2005 .00178 \mathrm{x}$.

[29] Verma V., Balasubramanian K., "Experimental and theoretical investigations of Lantana camara oil diffusion from polyacrylonitrile membrane for pulsatile drug delivery system", Material Science and Engineering, Vol. 41, pp. 292-300, 2014. DOI: https://doi.org/10.1016/j.msec.2014. 04.061 .

[30] Adiguzel A., Gulluce M., Sengul M., Ogutcu, H., Sahin F.,Karaman I., "Antimicrobial effects of Ocimumbasilicum (Labiatae) Extract”, Turkish Journal of Biology, Vol. 29, pp. 155-160, 2005.

[31] Gupta R., Ramesh C.K., Khasa Y.P., Singh A., "Bioethanol production from Lantanacamara (red sage): Pretreatment, saccharification and fermentation", Bioresource Technology, Vol. 101, pp. 8348-8354. 2010. DOI: 10.1016/j.biortech.2010.06.043.

[32] Suthar S., Sharma P., "Vermicomposting of toxic weed Lantana camara biomass: Chemical and microbial properties changes and assessment of toxicity of end product using seed bioassay", Ecotoxicology and Environmental Safety, Vol. 95, pp. 179-187, 2013. DOI: https://doi.org/10.1016/j.ecoenv.2013.05.034

[33] Misra N., Sharma M., Raj K., Dangi A., Srivastava S., Bhattacharya S.M., "Chemical constituents and antifilarial activity of Lantana camara against human lymphatic filariid Brugiamalayi and rodent filariid Acanthocheilonem a viteae maintained in rodent hosts", Parasitology Research, Vol. 100, no. 3, pp. 439-448, 2007. DOI: $10.1007 /$ s00436006-0312-y.

[34] Sathish R., Bhushan V., Natarajan K., "Antiulcerogenic 
activity of Lantana camara leaves on gastric and duodenal ulcers in experimental rats", Journal of Ethnopharmacology, Vol. 134, pp. 195-197. 2011. DOI: 10.1016/j.jep.2010.11. 049.

[35] SethR., Mohan M., Singh P., "Chemical composition and antibacterial properties of the essential oil and extracts of Lantana camara from Uttarakhand (India)", Asian Pacific Journal of Tropical Biomedicine, Vol. 2, pp. S1407-S1411, 2012. DOI: https://doi.org/10.1016/S2221-1691(12)604262.

[36] Begum S., Wahab A., Siddiqui B.S., "Ursethoxy acid, a new triterpene from Lantana camara". Natural Product Letter, Vol. 16, no.4, pp. 235-238. 2002. DOI: $10.1080 / 10575630290020523$.

[37] Cobos M.I., Rodriguez J.L., Oliva M.L., Demo M., Faillaci
S.M., Zygadlo, J.A. "Composition and antimicrobial activity of essential oil of Baccarisnotosergila", Planta Medica, Vol. 67, no. 1, pp. 84-86, 2001. DOI: $10.1055 / \mathrm{s}-2001-10633$

[38] Ates D.A., Erdogrul O.T., "Antimicrobial activities of various medicinal and commercial plant extracts", Turkish Journal of Biology, Vol. 27, pp. 157-155, 2003.

[39] Bowden B.F., Barre J.T., Coll J.C., Fuente V.E., Jesus J.D., Janairo G.C., Ragasa C.Y., "A bioactive triterpene from Lantana camara", Phytochemistry, Vol. 45 no. 2, pp. 321325, 1997. DOI: 10.1016/s0031-9422(96)00805-9.

[40] Moore J.D., Grover R.K., "Toximetric studies of fungicides beside the brown rot organisms, Sclerotiniafructicola and Sclerotinialaxa", Phytopathology, Vol. 52, pp. 876-874, 1962. 